\title{
The Effect of European Intellectual Property Institutions on Ghinese Outward Foreign Direct Investment 0 it
}

\author{
Nikolaos Papageorgiadis, ${ }^{1}$ Yue $\mathrm{Xu},{ }^{2}$ \\ and Constantinos Alexiou ${ }^{3}$ \\ 'University of Liverpool, UK, ${ }^{2}$ Cardiff University, UK, and ${ }^{3}$ Cranfield University, UK
}

\begin{abstract}
This study examines the role of the strength of the Intellectual Property (IP) institutions of 23 European countries in attracting Chinese Outward Foreign Direct Investment (OFDI) during the time period 2003-2015. Following a dynamic panel data analysis methodology, we find that the strength of IP institutions has a positive effect in attracting higher levels of OFDI from China. This is an important finding for the OFDI literature from emerging markets, since previous studies have researched this relationship from the OFDI perspective of developed countries. However, we also find a weak indication of a potential U-shaped relationship between the strength of IP institutions and Chinese OFDI. To better understand this relationship, we interact a European country's membership in the Former Eastern Bloc (FEB) with the strength of IP institutions and find a negative moderating effect. We therefore find that when investing in FEB countries, Chinese firms are attracted to weaker levels of IP institutional strength. The results of this study have important implications for future studies on the determinants of OFDI from emerging markets, as well as for European and Chinese businesses and policy-makers concerning the importance of IP institutional strength.
\end{abstract}

KEYwORDS China, Europe, institutions, intellectual property, OFDI

\section{INTRODUGTION}

This article investigates the effect of the strength of European Intellectual Property (IP) institutions on Chinese Outward Foreign Direct Investment (OFDI). Over the last two decades, the role of the strength of IP institutions of host countries in

- The Open Materials badge recognizes authors who deposit their research materials in an openaccess repository. The materials used in this study can be found at [https://osf.io/jpxat/quickfiles]. Details about the badge are available on the journal's website.

dI The Open Data badge recognizes authors who deposit their data (and statistical code, if necessary) in an open-access repository. The data used in this study can be found at [https://osf.io/jpxat/ quickfiles]. Details about the badge are available on the journal's website.

Corresponding author: Yue Xue (xuy63@cardiff.ac.uk) 
attracting or discouraging Foreign Direct Investment (FDI) has gained increasing attention in the literature (Branstetter, Fisman, Foley, \& Saggi, 2007; Khoury \& Peng, 2011; Lee \& Mansfield, 1996). This is because the strength of IP institutions can determine the extent to which firms can protect against IP infringement and effectively exploit their IP assets in a host country (Oxley, 1999). Most studies in the existing literature focus on the strength of the regulatory structure of IP institutions (law on the books) and find a positive effect in attracting OFDI from developed countries, such as the US (Lee \& Mansfield, 1996; Nicholson, 2007; Seyoum, 2006). However, there are two recent developments in the international business environment that have not been addressed by the existing literature to date.

First, Chinese OFDI activities have grown exponentially after China joined the World Trade Organisation (WTO) in 2001, with Chinese OFDI flows in Europe reaching US $\$ 55$ billion in 2014 (Le Corre \& Sepulchre, 2016). While expanding abroad, Chinese firms have also placed emphasis on building their portfolios of IP assets to support their business models. This is reflected in the growth of patent applications by Chinese residents in China, from 58,757 in 2003 to $1,010,406$ in 2015. Many of these patent applications were also filed in the IP institutions of foreign countries, with the numbers rising from 1,707 applications in 2003 to 42,154 in 2015 (WIPO, 2017). In fact, the number of Chinese patents filed abroad is nowadays similar to this from France, whose firms filed for 46,581 patents abroad in the year 2015 (WIPO, 2016). This suggests that Chinese OFDI in European countries includes investments from firms that have already established and growing (often through acquisitions) IP portfolios. Such investments are spread throughout Europe: examples include the establishment of greenfield Research and Development (R\&D) centres, such as Yili Dairy's development of an R\&D centre in the Netherlands (Wageningen University, 2014), Huawei's establishment of 18 R\&D centres in Europe (Huawei Europe, 2015) and Changan Automotive's development of two R\&D centres in the UK and Italy (Changan UK, 2017). Other Chinese investments aim to exploit their existing IP supported business models in Europe, as well as acquire and exploit European IP assets such as the acquisition of Imagination Technologies (the IP rich UK designer of graphic processors) by the Chinese firm Canyon Bridge (Bradshaw, 2017). Chinese OFDI also includes investments from less innovative firms that compete with IP light business models and aim to expand and capture market share in European markets. Therefore, the strength of IP institutions of host European countries could influence the effectiveness with which Chinese firms protect their IP and appropriate the returns from their investments in the development and exploitation of IP assets in Europe. However, there is currently no study in the existing literature (to our knowledge) on the effect of the strength of IP institutions on Chinese OFDI, or from emerging markets (EMs) in general.

Second, after the signing of the Trade-Related Aspects of Intellectual Property Rights (TRIPs) agreement, the strength of the IP regulatory institutions of most developed and developing countries that are members of WTO is now

(C) 2019 The International Association for Chinese Management Research 
relatively harmonised (Peng, Ahlstrom, Carraher, \& Shi, 2017). In contrast, the effectiveness with which the IP institutional agents enforce IP law in practice varies significantly in most WTO member countries (Brander, Cui, \& Vertinsky, 2017; Papageorgiadis, Cross, \& Alexiou, 2014). This is because the effectiveness of IP enforcement related institutional agents in a country is influenced by the underpinning norms and social cognitions regarding the legitimacy and acceptability of the IP regulatory environment. Although the TRIPs agreement introduced significant reforms to the IP regulatory environments of all WTO member countries, the new laws and regulations imposed by TRIPs are (often) foreign to the existing normative and cognitive IP institutional structures of a country (Brander et al., 2017). As a result, the IP enforcement agents of a country can often not perceive the post-TRIPs legal and regulatory reforms as fully acceptable and legitimate. Such an incongruence can affect the level and extent to which the IP institutional agents are committed to dedicating resources and effectively enforcing IP law in practice (Yang, Fryxell, \& Sie, 2008). Since existing studies mainly focus on the effect of the regulatory structure of IP institutions, it is important in the postTRIPs context to gain a better understanding of the effect of IP institutional strength on OFDI.

We take into consideration the above two developments and make two contributions to the literature by studying the effect of the strength of the IP institutions of 23 European countries on Chinese OFDI over the years 2003-2015. With regards to the first contribution of the study, we focus on the strength of enforcement related aspects of European IP institutions and find that it has a positive effect (at the 5\% level) on Chinese OFDI, which suggests that higher levels of IP institutional strength in a host country lead to higher levels of Chinese OFDI. Chinese companies are found to prefer operating in strong IP institutions, where they can successfully defend and exploit their internally developed or acquired IP assets. This is the first study on IP institutions and OFDI from the perspective of an emerging economy and the result is aligned with the existing literature on the effect of IP institutions on OFDI from developed countries (Nicholson, 2007; Seyoum, 2006; Smarzynska Javorcik, 2004). However, the results also reveal some weak evidence of a U-shaped relationship (at the $10 \%$ level) between the strength of IP institutions and Chinese OFDI. This leads us to the second contribution of this study, where in the process of finding more evidence to explain the potential of a U-shaped relationship, we find that a country's membership to the Former Eastern Bloc (FEB) negatively moderates the effect (at the 5\% level) of the strength of IP institutions on Chinese OFDI. The findings suggest that when investing in countries that were members of the FEB, Chinese companies prefer to invest in weaker IP institutions. This is because the general institutional normative and cognitive structures of FEB countries have many similarities to those of China, due to FEB and Chinese institutions going through the process of transitioning from centrally planned to market economies. Therefore, in FEB countries Chinese firms are found to prefer weak levels of IP institutional strength, since the 
weak levels of IP institutional strength can be more predictable (in terms of ineffectiveness) and the risk of facing major disruption from a potential IP infringement lawsuit from competitors is lower. Importantly, through exercising their strong skills in developing informal network ties, Chinese firms can expect that they could influence enforcement related IP institutional agents in an FEB host country with weak IP institutional strength and achieve their desired institutional conditions of a predictably weak appropriability regime. Overall, the contributions of this study provide important insights regarding the effects of variable levels of IP institutional strength on Chinese OFDI and allow us to draw managerial and policy-making implications.

\section{THEORETIGAL BACKGROUND AND HYPOTHESES}

\section{IP Institutions}

Institutions are human and social constructs which determine the rules, procedures, powers of enforcement, and norms of behaviour that constrain and guide human and organisational behaviour (North, 1990). Specifically, Scott (1995: 53) defines institutions as 'regulative, normative and cognitive structures and activities that provide stability and meaning to social behaviour'. Following Scott's (1995) definition, the regulative structure of institutions consists of laws, explicit regulations, and supporting structures which aim to provide a stable and transparent environment to the economic actors transacting within the boundaries of an institution (Orr \& Scott, 2008). The regulative structure of an institution relates to laws and regulations that are set by the government of a country and the governmental bodies/agencies which carry oversight and administration responsibilities. The regulative structure includes the legislative framework which, for example, details the administrative and enforcement procedures in a country. The normative structure includes tacit values and rules that are established and integrated within an institution, which determine what the institutional players consider as legitimate and acceptable practice (Scott, 1995). The cognitive structure relates to societal values and includes the perceptions and explanations of social reality as seen by actors operating within the institution (Scott, 1995). The normative and cognitive structures jointly determine the extent to which the requirements set by the regulative structure are perceived as legitimate and acceptable by the institutional actors who carry out the enforcement of the regulations in practice (such as the judiciary, police, and customs enforcement agencies). The extent to which the normative and cognitive structures are aligned (or not) with the regulative structure therefore influences the actual efforts of the institutional actors in effectively enforcing the regulations. This is because when the normative and cognitive structures are incongruent or competing with the regulative structure, activities that are illegal according to the law on the books can be seen as legitimate and can be tolerated by the enforcement related institutional actors (Justin, 
Tihanyi, Ireland, \& Sirmon, 2009). In this case, the normative and cognitive institutions undermine the regulatory structure of an institution and lead to the ineffective enforcement of the law in practice.

Following the definition by Scott (1995), IP institutions are comprised of the regulative structure, which relates to IP specific regulations and the normative and cognitive structures that determine the perceived legitimacy and acceptability of the IP regulations by the institutional actors who operate within the IP institution and are responsible to enforce the regulations in practice. The regulative structures of IP institutions of countries that are members of the WTO have significantly changed after the signing of the TRIPs agreement in 1994. The TRIPs agreement required signatory countries to undertake significant reforms in their IP regulatory institutions '...to adapt their laws to the minimum standards of IPR (intellectual property rights) protection' (WHO, 2017). The aim of the TRIPs agreement was to uniformly strengthen and achieve a relative harmonization of the regulative structures of the IP institutions of WTO member countries (Grossman \& Lai, 2004). In particular, the TRIPs agreement determined the minimum regulatory framework that the signatory countries are obliged to offer. The adoption of such regulatory reforms was a significant task for most developing countries such as China, which needed to adopt significant changes in its IP regulatory institution (Thomas, 2017). After implementing the TRIPs agreement, however, China now offers a regulatory system that is often commented as being well crafted and aligned with the WTO expectations (Peng et al., 2017; Taubman, Wager, \& Watal, 2012).

The strengthening policy trajectory of signatory countries that reformed their IP regulatory institutions after TRIPs led to most countries offering similar levels of availability of IP law on the books. This is clearly illustrated by the latest scores of the index of patent protection by Park (2008), which counts the existence (or not) of specific patent-related laws and standards but does not capture the effectiveness with which these laws are enforced in practice (Brander et al., 2017; Maskus, 2014). ${ }^{[1]}$ Depending on the number of available laws, the IP regulative institutions of countries in the Park (2008) index receive a score between 0 to 5, where a score of 5 indicates to countries offering strong patent protection (in terms of availability of patent law on the books) and a score of 0 indicates to countries offering weak (or non-existent) patent protection. For example, in 2005 and 2010, FEB countries, such as Poland, achieved high scores that are similar to the level of regulatory protection of most European countries, with minimal/minor score differences. This suggests that the TRIPs reforms have now achieved a relative harmonization of the regulatory structures of most developed and developing countries which are members of the WTO, especially in terms of a high level of minimum IPR legal standards (Papageorgiadis et al., 2014; Peng et al., 2017).

In contrast, the normative and cognitive structures of IP institutions continue to vary significantly between countries. This is because while the TRIPs agreement set obligations about IP law on the books in relation to the available legal 
mechanisms for the enforcement of IP (which is part of the regulatory structure of the institution), it did not set any obligations about how IP law should be enforced in practice by the IP institutional agents (Taubman et al., 2012). The intensity and extent of implementation of IP law in practice therefore depends on the IP institutional agents and on the way that the normative and cognitive structures of the IP institution are aligned with the regulatory structure. Such an alignment is particularly important for IP institutions, since the regulatory structures of most countries have been developed ' ... in response to externally imposed requirements for joining the WTO...' and not in accordance with a country's established IP normative and cognitive structures (Brander et al., 2017: 9). The IP normative and cognitive structures influence the institutional agents involved in the enforcement of IP in three ways. First, the two institutional structures determine the level and extent to which the government and public enforcement authorities consider it to be a legitimate and acceptable practice to enforce IP rights. This affects the level and extent to which official authorities actively engage with IP owners and are committed to dedicate resources for monitoring markets and prosecuting identified cases of IP infringement (Yang et al., 2008). Second, perceptions concerning the legitimacy and acceptability of IP influence the effectiveness of a country's judicial system in terms of its efficiency, fairness, and imposition of appropriate penalties that can deter convicted parties from repeating the infringement of IP (Ostergard, 2000; Papageorgiadis et al., 2014; Yang et al., 2008). Third, the normative and cognitive structures also influence the effectiveness of other private and public agencies that administer IP rights such as the IP office of a country, in terms of its efficiency, stringency, and transparency in order to guarantee that the administration process is fair, certain, and predictable (Papageorgiadis et al., 2014).

Overall, in countries where the normative and cognitive structures are aligned with the regulatory structure of the IP institutions, the IP institutional agents are expected to effectively enforce IP law in practice. Firms can therefore anticipate facing limited transaction costs and smoothly and effectively enforce their IP against infringing firms when they operate in countries where the institutional structures are aligned (Papageorgiadis et al., 2014). In contrast, firms can anticipate high transaction costs and limited effectiveness in enforcing their IP when operating in countries where the institutional structures are incongruent. The cross-country differences in the effectiveness of enforcing IP rights worldwide are illustrated in the index of patent systems strength by Papageorgiadis et al. (2014). In this index, countries achieve scores in the range of 0 to 10 , where high scores indicate IP institutions where the enforcement of patent rights is effective and patent owners experience low transactions costs, and vice versa. As illustrated in Table 2, the strength of enforcement in IP institutions varies significantly between the same countries presented in Table 1. Contrary to the regulatory structure of IP institutions, FEB countries achieved low scores that are clearly different when compared to the level of enforcement effectiveness of other European countries, with major/medium score differences. This suggests 
Table 1. The strength of patent law (on the books) in 23 European countries

\begin{tabular}{|c|c|c|}
\hline \multirow[b]{2}{*}{ Countries } & \multicolumn{2}{|c|}{$\begin{array}{c}\text { Index of Patent Protection Strength } \\
\text { (Park, 2008) }\end{array}$} \\
\hline & Year 2005 & Year 2010 \\
\hline Austria & 4.33 & 4.33 \\
\hline Belgium & 4.67 & 4.67 \\
\hline Czech Republic & 4.33 & 4.33 \\
\hline Denmark & 4.67 & 4.67 \\
\hline Finland & 4.67 & 4.67 \\
\hline France & 4.67 & 4.67 \\
\hline Germany & 4.67 & 4.67 \\
\hline Greece & 4.47 & 4.47 \\
\hline Hungary & 4.33 & 4.33 \\
\hline Ireland & 4.67 & 4.67 \\
\hline Italy & 4.67 & 4.67 \\
\hline Netherlands & 4.67 & 4.67 \\
\hline Norway & 4.29 & 4.42 \\
\hline Poland & 3.88 & 4.00 \\
\hline Portugal & 4.33 & 4.33 \\
\hline Russia & 3.68 & 3.68 \\
\hline Slovakia & 4.21 & 4.33 \\
\hline Spain & 4.33 & 4.33 \\
\hline Sweden & 4.54 & 4.54 \\
\hline Switzerland & 4.21 & 4.21 \\
\hline Turkey & 4.01 & 3.88 \\
\hline United Kingdom & 4.54 & 4.54 \\
\hline Ukraine & 3.68 & 3.88 \\
\hline
\end{tabular}

that while TRIPs reduced some of the regulatory variance between IP institutions, differences in effectiveness still prevail (Kanwar \& Evenson, 2009). The regulative structure provides the foundation for a strong IP institution; however, it needs to be amalgamated with effective and efficient IP enforcement efforts by the relevant institutional actors. While IP systems internationally have achieved a relative regulatory harmonisation of their minimum standards, the effectiveness of enforcement which is underpinned by the normative and cognitive structures of IP institutions continues to differ considerably. Therefore, in the post-TRIPs implementation period, the normative and cognitive structures have an important, dominant role in determining the effectiveness of IP institutions.

\section{The Effect of IP Institutions on FDI}

FDI theory suggests that the efficient functioning of institutions has a positive influence on the location selection, mode of entry, and technology transfer strategies of multinational firms (Dunning, 2006; Guler \& Guillén, 2010; Henisz \& Swaminathan, 2008). This is because well established, strong institutions are associated with a stable and low transaction cost investment environment (Delios \& 
Table 2. The strength of the effectiveness of patent enforcement in 23 European countries for the year 2013

\begin{tabular}{lc}
\hline \hline & \\
Countries & $\begin{array}{c}\text { Index of Patent Systems Strength } \\
\text { Papageorgiadis et al., 2014) }\end{array}$ \\
\hline Austria & 7.1 \\
Belgium & 7.6 \\
Czech Republic & 5.2 \\
Denmark & 9.0 \\
Finland & 9.0 \\
France & 7.2 \\
Germany & 8.0 \\
Greece & 4.1 \\
Hungary & 5.7 \\
Ireland & 7.3 \\
Italy & 4.6 \\
Netherlands & 8.5 \\
Norway & 8.6 \\
Poland & 6.0 \\
Portugal & 6.3 \\
Russia & 3.2 \\
Slovakia & 4.8 \\
Spain & 6.5 \\
Sweden & 8.8 \\
Switzerland & 8.7 \\
Turkey & 5.1 \\
Ukraine & 7.6 \\
\hline \hline & 3.1 \\
\hline
\end{tabular}

Henisz, 2003; Lu, Liu, Filatotchev, \& Wright, 2014; Meyer, Estrin, Bhaumik, \& Peng, 2009). As Dunning (2006: 210) highlighted: '...the extent, content and quality of a country's institutions and their upgrading, as they affect each and every individual and organization involved in the wealth creating process, are likely to impact seriously on the quantity and form of inbound - and for that matter outbound - TNC activity...'. Similar to other institutions, strong IP institutions can lower the levels of transaction costs of IP owners who engage with the IP institution, reduce uncertainties and therefore attract FDI. Given that the regulative IP structures of most host countries have significantly strengthened after TRIPs, FDI will depend on the level of effectiveness of IP institutional agents in enforcing IP as determined by the underpinning normative and cognitive institutional structures.

Over the last 25 years the role of strong IP institutions in attracting or discouraging FDI globally has attracted significant attention from international business researchers. Empirical studies have focused either on the effect of IP institutions on inward FDI from multiple countries or on the effect of IP institutions on the OFDI originating from one country. With regards to the effect of IP on inward FDI, a number of mainly pre-TRIPs studies have used multi-country samples 
and provided empirical evidence that strong IP institutions particularly in developing countries have a positive effect on attracting inward FDI flows (e.g., Nicholson, 2007; Seyoum, 2006; Smarzynska Javorcik, 2004). Two studies focused on the effects of the regulatory structure of host IP institutions on inward FDI and found a positive relationship (Seyoum, 2006; Smarzynska Javorcik, 2004). Smarzynska Javorcik (2004) also included a second variable to account for the strength of the enforcement related aspects of host IP institutions of transition economies and found the same positive relationship with inward FDI. Such positive effects have also been confirmed for all country samples considered in the study of Seyoum (2006), including those of countries with weak regulatory IP institutional strength. In contrast, Khoury and Peng (2011) studied the IP regulatory reforms of 18 Latin American countries and found that those countries that reformed their IP institutions earlier than the others in the sample experienced a negative effect on their inward FDI flows. However, the authors still found a positive effect on inward FDI for those early IP reforming countries that had an established innovation base at the time of the reforms. Finally, an early study by Kondo (1995) found no relationship between stronger IP levels and inward FDI.

In relation to the effect of the strength of IP institutions on OFDI, all studies in the existing literature have focused on the outward flows originating from developed countries that offer strong IP institutions such as the US, Japan, Germany, and France. The results are generally consistent in that host countries with strong IP institutions are found to attract higher OFDI levels (Bascavusoglu \& Zuniga, 2002; Branstetter et al., 2007; Lee \& Mansfield, 1996; Ushijima, 2013). There is strong empirical evidence to suggest that US OFDI is positively affected by the strength of the regulatory structure of IP institutions (Branstetter et al., 2007; Lee \& Mansfield, 1996; McCalman, 2004). For example, Branstetter et al. (2007) found patent regulatory reforms over the years 1989-1999 to have a positive effect on US OFDI, especially from patent intensive industries. This result was also confirmed by Canals and Şener (2014) but only for the high-tech industries of the sample, as the effect of strong IP on low-tech industries was found to be insignificant. Strong levels of patent regulations were also found to be important for US OFDI from Hollywood (McCalman, 2004) as well as to influence the volume and composition of US FDI (Lee \& Mansfield, 1996).

The effect of the regulative structures of IP institutions is also found to stimulate OFDI from Japan and Germany but not from France (Bascavusoglu \& Zuniga, 2002; Pfister \& Deffains, 2005; Ushijima, 2013). Ushijima (2013) found a positive relationship between the strength of patent legislation of 58 countries and Japanese OFDI levels for the years 1985-2004. Japanese OFDI is particularly found to be influenced by the strength of patent legislation when investing in countries with high imitative abilities (Ushijima, 2013). The same effect applies for the OFDI from Germany to 38 countries over the years 1992-2000 (Bascavusoglu \& Zuniga, 2002). In contrast, strengthening IP levels are found to have no effect on the OFDI from France for the years 1959-1994 (Pfister \& Deffains, 2005). 
More specifically, the strengthening of the regulative structures of IP institutions is found to have a negative effect on French OFDI in those countries with a large market as well as those that are characterized by relatively low levels of R\&D intensity (Pfister \& Deffains, 2005). Overall, the existing literature generally suggests that strong IP institutions have a positive effect on OFDI from developed countries.

\section{The Effect of IP Institutions on Chinese OFDI}

While the existing literature studying the effect of strong IP institutions on OFDI appears to be maturing, the potential effect of host country IP institutional strength on OFDI originating from EMs such as China has not yet received scholarly attention. Chinese OFDI is faced with significant IP institutional challenges especially when investing in geographic regions such as Europe, where the strength of the effectiveness of patent enforcement varies significantly between different European countries. As Table 2 shows, some European countries such as Germany, Denmark, and the Netherlands offer strong levels of IP enforcement, whereas others such as Greece, Poland, and Slovakia offer weak levels of IP enforcement, similar to the level of IP enforcement strength offered in China. This is because even though the IP regulatory structure of most European countries is generally strong, partly due to the influence of international treaties such as the TRIPs agreement and European agencies such as the European Patent Office (EPO) (EPO's members include countries outside the European Union), there is currently no similar co-ordination or obligation for the enforcement related aspects of IP institutions. IP enforcement is organised and delivered at the national level and the strength of effectiveness is affected by the national normative and cognitive IP structures that underpin the actions of local institutional agents. Although there are plans to centralise certain enforcement related aspects of the IP institutions at the European level, such as the proposals for the Unified Patent Court, these have not yet materialized (Unified Patent Court, 2017). Therefore, the strength of IP institutions in European countries (but also most developed and developing WTO member countries) is predominantly determined by the way that the normative and cognitive structures affect IP institutional agents and the effectiveness with which they enforce IP law in practice. Overall, studying the effect of the strength of the IP institutions of European countries on OFDI levels from China showcases how different levels of IP institutional strength in one IP diverse geographic region can affect Chinese OFDI.

As the institutional escapism view suggests, weak institutional and environment factors and high institutional costs at home may push Chinese firms to invest abroad in pursuit of more efficient institutions outside China (Boisot \& Meyer, 2008; Luo, Xue, \& Han, 2010; Witt \& Lewin, 2007; Yamakawa, Peng, \& Deeds, 2008). The Chinese IP institutional conditions have not been conducive to the effective exploitation of IP assets by Chinese firms in their home country (Nolan, 2001; Rui \& Yip, 2008). On the one hand, IP rights are not a prerequisite to achieving commercial

(C) 2019 The International Association for Chinese Management Research 
success in the home market due to the weak enforcement of IP laws. Even when Chinese firms are found to infringe the IP of other firms, the resulting penalties, damages, or other legal implications are often disproportionately small compared to the revenues, advances in know-how, and commercialization achieved $(\mathrm{Li}$, 2002a, 2002b). The normative and cognitive structures in countries with strong IP institutions are aligned with the regulatory structures and the institutional actors involved in the enforcement of IP rights implement the letter of the law in practice. Therefore, countries with strong IP institutions are expected to provide effective enforcement to the rights of the IP-owning firms and would allow Chinese firms to successfully appropriate the returns from their R\&D investments and internally developed or acquire IP assets.

Chinese investments in Europe have drastically increased over the last fifteen years, with Chinese firms investing $\$ 55$ billion US dollars in 2014 alone (Le Corre \& Sepulchre, 2016). Chinese firms in Europe engage in both greenfield investments as well as mergers and acquisitions with local companies. A number of Chinese firms have undertaken greenfield investments in Europe to set up R\&D centres as well as to penetrate European markets by utilizing their existing IP asset-supported business models. For example, Huawei established 18 R\&D centres in eight European countries since entering Europe (Huawei Europe, 2015). Operating in countries with strong IP institutions can allow firms like Huawei to confidently innovate and efficiently commercialize their new innovations in a tight appropriability regime, since IP leakage and IP theft are expected to be effectively prosecuted and penalised by the IP enforcement authorities of the host country (Teece, 1986). Furthermore, other Chinese firms that aim to access European markets, but operate with business models that are easy to copy, also benefit from operating in countries with strong IP institutions with effective IP enforcement. For instance, this is the case for firms in the bicycle rental market such as Mobike (owned by Beijing Mobike Technology Co., Ltd), whose fully station-less premium bicycle renting business model can be easily replicated by competing firms (Cendrowski, 2017). Mobike's business model is supported by 30 internally developed patents relating to e.g., the 'smart lock' system found in all its bicycles as well as the design of their magnesium alloy wheels (Zhang \& Yan, 2017). Operating in countries with strong IP institutions can enable companies like Mobike (which entered the UK in 2017) to utilize their business models and benefit from their innovations while seeking to block competing firms who may infringe their IP assets. With regards to mergers and acquisitions, a number of studies indicate that Chinese OFDI is also aimed at accessing and acquiring strategic assets, such as IP assets and brand names (Buckley, Clegg, Cross, Liu, Voss, \& Zheng, 2007; Luo \& Tung, 2007; Rugman \& Li, 2007). For example, Chinese investors have acquired traditional IP intensive European manufacturers, such as Geely's acquisition of the Swedish automotive manufacturer Volvo in 2008 (Clark, 2010), and China National Chemical Corporation's (ChemChina) acquisition of the Italian tyre manufacturer Pirelli in 2015 (Arosio \& Masoni, 2015). 
Operating in countries with strong and effective IP institutions can enable Chinese firms to successfully defend, exploit, and profit from their new IP assets. Overall, we expect that strong IP institutions will attract higher levels of Chinese OFDI, which leads to the development of the first hypothesis:

Hypothesis 1a: European countries that provide strong IP institutions attract higher levels of Chinese OFDI.

Chinese OFDI in Europe, however, also includes the investments of firms with IP light business models, which can be exposed to the risk of IP litigation by competitors in the IP institution of a host country. The potential threat of IP litigation from competing firms with established IP portfolios can jeopardise the investments of Chinese firms in countries with effective IP institutions. This is because Chinese firms could be faced with potentially heavy costs of IP litigation, settlement costs, and a potential prolonged threat of a ban from operating in a host market. The average cost of patent litigation is estimated to be in the region of $\$ 2.8$ million and the average disruption that firms face due to IP litigation is found to be between 18 and 36 months (De Leon \& Donoso, 2017). For example, firms sued for patent infringement in Germany experienced negative effects on their performance, irrespective of settling or losing a patent trial (Schliessler, 2015). This negative effect is especially evident in firms that are small or less experienced with patent litigation (Schliessler, 2015). Operating in countries with strong IP institutions, therefore, can also increase the transactions costs and risks to Chinese firms with IP light business models. Investing in countries where IP institutions are weak in terms of ineffective IP enforcement can enable such firms to avoid IP litigation from competing firms, or to anticipate that any potential IP litigation from competitors would be unlikely to significantly disrupt their investments and affect their performance. Importantly, since Chinese firms are familiar with operating in a weak IP enforcement institution at home, they may find it more suitable and effective to invest in countries where IP enforcement is weak, so that they can successfully exploit their existing home country business model.

In addition, Chinese firms are expected to invest less in countries where the strength of IP institutions is medium, due to the unpredictability of the level of IP enforcement effectiveness. On the one hand, Chinese firms with established IP portfolios could be faced with high transaction costs when engaging in IP enforcement activities in such host markets, making it difficult to effectively profit from their IP. This is because it is questionable if countries with medium IP institutional strength can provide the necessary environment in which firms can effectively and efficiently enforce and exploit their IP rights (Papageorgiadis \& Sharma, 2016). On the other hand, Chinese firms with IP light business models may invest less in countries with medium IP institutional strength since the likelihood of facing successful IP enforcement actions against them is also higher and unpredictable. We therefore expect that:

(C) 2019 The International Association for Chinese Management Research 
Hypothesis 1b: The strength of European IP institutions has a U-shaped relationship with Chinese Outward FDI.

China and European countries that were members of the FEB have experienced similar changes in their institutional infrastructure while in the process of transitioning from planned towards market-based economies (Peng \& Heath, 1996). Taking Russia and China as an example, both countries followed similar ways to configure policies such as for the development of their innovation systems (Li, Butel, \& Wang, 2017), as well as both their institutional contexts emphasis on establishing 'relational networks' (Hitt, Ahlstrom, Dacin, Levitas, \& Svobodina, 2004: 175). Although FEB countries have drastically changed the regulatory structures of their institutions, the normative and cognitive structures are still experiencing a slow process of transformation (Meyer \& Peng, 2005). The new regulatory structures are not yet fully accepted or seen as legitimate by the institutional agents of FEB countries and this affects the strength and quality of the enforcement of the law in practice. This is because '...the shortage economy during the communist era has institutionalised some of the informal networking practices...' (Meyer \& Peng, 2005: 612). Such informal practices are manifested when 'agency relationships are complex and vaguely defined' (Filatotchev, Wright, Uhlenbruck, Tihanyi, \& Hoskisson, 2003: 603; Meyer \& Peng, 2005) and personal relationships (Ledeneva, 1999) can play a dominant role in successful business activity in FEB countries. Therefore, legislative bodies can still suffer from high levels of corruption, the judiciary can be inconsistent, and enforcement agencies may not be effective in monitoring and enforcing the law in practice (Anttonen, Tuunanen, \& Alon, 2005; Carruthers \& Ariovich, 2004). The institutions of FEB countries are therefore considered to be relatively weak and tend to be characterized by inconsistency and instability (Meyer, 2001).

Operating in institutionally weak countries is generally expected to increase the transaction costs of foreign firms since they 'have to adapt their strategies to the local institutions and reduce exposure to highly imperfect markets' (Meyer, 2001: 375). However, this is not expected to be the case for most Chinese firms since, to succeed in their home country, they have already developed strong capabilities in building business and institutional network ties with institutional agents (Buckley et al., 2007; Peng, 1997; Yiu, Lau, \& Bruton, 2007). Therefore, while the transaction costs of operating in FEB countries may be high for most firms from developed economies (Meyer, 2001), the familiarity with the normative and cognitive institutional conditions in FEB countries can be desirable and a source of competitive advantage for Chinese firms (Peng, 1997; Peng \& Heath, 1996). The weak institutional conditions in FEB countries may be particularly attractive to Chinese firms with both established (internally developed or acquired) and light IP portfolios. This is because the weaker the overall and IP institutional conditions in a host country, the higher the opportunities for Chinese firms to successfully navigate and mobilize the institutional agents to their advantage through the building of network 
and institutional ties (Cuervo-Cazurra \& Genc, 2008, 2011). On the one hand, Chinese firms with established IP portfolios will find it easier to operate with the same business model when operating in FEB countries as the one used at home, since they are familiar with the IP and overall institutional challenges and will seek to replicate their home-based approach to appropriating the returns of their IP assets. Therefore, while Chinese firms will not be able to achieve the tight appropriability conditions as in countries with strong IP institutions, they are expected to select investments that are more suitable for the capturing of market share in FEB countries, and follow the same business models as the ones at home. On the other hand, and in line with the discussion in the previous section, Chinese firms with IP light business models are also expected to face limited exposure to IP litigation in a FEB host country. In fact, the weaker the strength of the IP institution of a FEB country, the clearer and more predictable the IP institutional conditions are expected to be for IP light Chinese firms. We therefore expect that:

Hypothesis 2: The relationship between the strength of IP institutions and Chinese OFDI is negatively moderated by a host country's membership of the Former Eastern Bloc.

\section{METHOD}

We formulate and estimate three different models for a sample of 23 European countries during the period 2003-2015. In particular, the first model attempts to capture the impact of the strength of IP institutions as well as the impact of a vector of control variables on Chinese OFDI levels; in the second model, we introduce a squared term of the index measuring the strength of IP institutions to capture potential nonlinearities existing in the specification of the model. In the third model, we interact a dummy variable that captures if a country was a member of the FEB (or not) with the strength of IP institutions to identify if it moderates the effect of host country IP institutions on Chinese OFDI. The 23 European countries included in the study are presented in Table 3.

\section{The Variables}

Dependent variable. The dependent variable of this study is annual Chinese outward FDI flows for the period 2003-2015 in 23 European countries. Data on Chinese OFDI are sourced from the publicly accessible OFDI dataset provided by the Ministry of Commerce of the People's Republic of China (MOFCOM) in the Statistical Bulletin of China's Outward Foreign Direct Investment (MOFCOM, 2009, 2015). The use of OFDI flow data is in line with the flow data used by previous studies in the literature, such as Buckley et al. (2007) who used OFDI flow data and Khoury and Peng (2011) who used inward FDI flow data.

(C) 2019 The International Association for Chinese Management Research 
Table 3. List of European host countries included in the study

\begin{tabular}{ll} 
Austria & Norway \\
Belgium & Poland \\
Czech Rep. & Portugal \\
Denmark & Russia \\
Finland & Slovakia \\
France & Spain \\
Germany & Sweden \\
Greece & Switzerland \\
Hungary & Turkey \\
Ireland & UK \\
Italy & Ukraine \\
Netherlands & \\
\hline
\end{tabular}

Notes: ${ }^{(1)}$ Turkey is included in the dataset of European countries because: a) it is a candidate country in the process of joining the European Union since 1987, and b) Turkey and the European Union have signed and implemented a Customs Union agreement on the $31^{\text {st }}$ of December 1995.

Independent - control variables. The main independent variable of this study is the strength of enforcement of European IP institutions, which is used to proxy for the effect of normative and cognitive IP structures on IP institutional agents involved in the enforcement of IP law in practice. We use the index of Papageorgiadis et al. (2014) to estimate the strength of enforcement of IP institutions. This index follows the theoretical underpinnings of transaction cost theory and estimates the level of transaction costs that IP-owning firms face when engaging with enforcement related institutional agents of a national patent system. A country's score is the aggregate of three transaction cost constructs, namely: a) servicing costs, b) property right protection costs, and c) monitoring costs. The monitoring cost construct measures the costs that firms experience when they engage with the enforcement agencies of a country. The property rights protection cost construct measures the costs that originate from the effectiveness of the judiciary of a country. The servicing cost construct accounts for the efficiency and effectiveness of the administration process by public and private agencies. High scores in the index indicate an effective IP institution, where IP-owning firms experience low transaction costs when interacting with IP institutional agents and are able to effectively enforce their IP. Lower scores suggest that IP-owning firms are faced with an ineffective IP institution, and therefore find it difficult to enforce their rights.

We incorporate in our model a number of control variables that have been used inter alia as main determinants of outward FDI by previous research studies in the literature (e.g., Buckley et al., 2007; Kang \& Jiang, 2012; Kolstad \& Wiig, 2012). These are: GDP growth rate, population, exchange rate, geographical distance between the host economy and China, inflation, openness, a squared term of the index of IP strength, a dummy variable capturing past membership in FEB countries in the dataset, and a slope dummy where we interact the dummy with the IP index. For a more comprehensive review, see Chakrabarti (2001) and Blonigen (2005). 
The growth rate of GDP is inserted to capture the market potential of an economy, whilst population is used to proxy for the market size of the respective economies. ${ }^{[2]}$ Existing evidence suggests that market potential and market size are positively related to FDI inflows since economic growth acts as a catalyst for the efficient utilization of resources and the exploitation of economies of scale via FDI (Chakrabarti, 2001; UNCTAD, 1998). Recently, additional evidence suggests that Chinese multinationals target large and growing markets in particular (Buckley et al., 2007; Kang \& Jiang, 2012; Kolstad \& Wiig, 2012). An additional independent variable that we have incorporated in our model is the exchange rate, which is a proxy for the real effective exchange rate (Buckley et al., 2007). An appreciated exchange rate in a host country discourages inward FDI, whilst a depreciation of the exchange rate encourages inward FDI, as foreign currency denominated assets become more affordable (Kohlhagen, 1977; Logue \& Willet, 1977; Stevens, 1993). It is expected that a relative depreciation of the host country's currency would lead to an increase in Chinese OFDI. Geographical distance is another variable that serves as a determinant of OFDI. Loungani, Mody, and Razin (2002) argue that the flow of FDI to nearby countries is predicted to be greatest, suggesting that a negative effect of geographic distance on the flow of FDI is envisaged. Inflation, apart from distorting the real picture of the economy, creates uncertainty and discourages market-seeking FDI (Buckley et al., 2007). It may also lead to domestic currency devaluation, as well as discouraging export-oriented FDI through increases in the price of locally sourced inputs. As a result, higher levels of inflation rate in a host country are expected to be negatively related to Chinese OFDI. The level of openness to trade of a host country is also widely considered to attract FDI investments. The more extrovert, and hence the more open a country is to international trade, the more likely it is to attract FDI (Chakrabarti, 2001; Kang \& Jiang, 2012; Wei, Zheng, Liu, \& Lu, 2014). The lagged dependent OFDI variable reflects the dynamic specification of our model and is envisaged as acting as a catalyst in attracting future OFDI flows. We expect that past success in attracting inward investment is likely to have a positive effect on future inward investment flows. We also incorporate a dummy variable in the estimation, which captures the potential impact of past membership of the FEB, and expect that it will have a positive effect in attracting Chinese OFDI due to the overall institutional similarities between the FEB countries and China. We furthermore incorporate a slope dummy in the estimation where the index of Papageorgiadis et al. (2014) is allowed to interact with the FEB dummy variable to test Hypothesis 2. Table 4 below includes a description of all the variables, details of their measurement and the sources from where we obtained the data.

\section{Model Specification}

The empirical specification of the OFDI regressions is a variant of the standard specifications encountered in the literature (see Buckley et al., 2007; Kolstad \& 
Table 4. Variable description, measurement, and sources

\begin{tabular}{|c|c|c|}
\hline Variable & Description/Measurement & Data Source \\
\hline LOFDI & $\begin{array}{l}\text { Natural log of Outward FDI from China to host country; } \\
\text { Unit: million-USD }\end{array}$ & $\begin{array}{l}\text { MOFCOM }(2009 \text {, } \\
2015)\end{array}$ \\
\hline INF & $\begin{array}{l}\text { Inflation - Consumer Price Inflation (CPI) growth rate of the } \\
\text { host country; CPI base year } 2010\end{array}$ & OECD (2016) \\
\hline GDP & $\begin{array}{l}\text { GDP growth rate of the host country (based on GDP per } \\
\text { capita in USD) }\end{array}$ & $\begin{array}{l}\text { The World Bank } \\
(2017)\end{array}$ \\
\hline LPOP & Natural log of population of the host country & $\begin{array}{l}\text { The World Bank } \\
(2017)\end{array}$ \\
\hline LOP & $\begin{array}{l}\text { Natural log of openness of the host country; Measured by } \\
\text { calculating Imports + Exports / GDP }\end{array}$ & $\begin{array}{l}\text { The World Bank } \\
(2017)\end{array}$ \\
\hline LDIST & $\begin{array}{l}\text { Natural log of geographical distance between Beijing and the } \\
\text { capital city of the host country; Unit: KM }\end{array}$ & Geobytes.com (2017) \\
\hline LREER & $\begin{array}{l}\text { Natural log of real effective exchange rate; Unit: LCU per } \\
\text { US\$, period average }\end{array}$ & $\begin{array}{l}\text { The World Bank } \\
(2017)\end{array}$ \\
\hline IPS & Index of patent systems strength & $\begin{array}{l}\text { Papageorgiadis et al. } \\
(2014)\end{array}$ \\
\hline IPSSQR & Index of patent systems strength squared & $\begin{array}{l}\text { Papageorgiadis et al. } \\
(2014)\end{array}$ \\
\hline DUM & $\begin{array}{l}\text { Dummy variable assuming the value of } 1 \text { for Former Eastern } \\
\text { Bloc countries and } 0 \text { for the rest of the countries in sample }\end{array}$ & \\
\hline DUM*IPS & $\begin{array}{l}\text { Interaction term of index of patent systems strength with } \\
\text { dummy variable of Eastern European countries }\end{array}$ & \\
\hline
\end{tabular}

Wiig, 2012; Ramasamy, Yeung, \& Laforet, 2012). In view of the dynamic component of our regression specification as well as the measuring of the relationship between OFDI and the macroeconomic variables, especially GDP growth, openness and the real effective exchange rate, endogeneity concerns are raised (see Walsh \& You, 2010). To address these, we utilize the Generalized Method of Moments (GMM) originated by Holtz-Eakin (1988) and further developed by Arellano and Bond (1991) and Arellano and Bover (1995). The GMM approach can overcome a number of econometric problems encountered during estimation, such as: bi-directional causality between variables; the possible endogeneity of explanatory variables, as well as omitted variable biases; time invariant country characteristics (fixed effects), which may be correlated with the explanatory variables; and the presence of autocorrelation (Anderson \& Hsiao, 1981; Caselli, Esquivel, \& Lefort, 1996). A more comprehensive insight relating to the technical aspects of the underlying methodological framework is provided by Arellano and Bover (1995).

The dataset used spans the period from 2003 to 2015, consisting of $\mathrm{N}$ cross sectional units, denoted $i=1, \ldots, \mathrm{N}$ observed at $\mathrm{T}$ time periods, denoted $t=1, \ldots$, T. More specifically, $y$ is a $(T \mathcal{N} \times 1)$ vector of endogenous variables, $x$ is a $(\mathcal{T N} \times k)$ matrix of exogenous variables, which does not include a column of units for the constant term. In this context, we collated data for a cross-section of 23 European economies $(\mathcal{N}=23)$, over a period of 13 years $(T=13)$. 
Apart from establishing the significance of potential determinants of OFDI, the main objective of this study is to effectively gauge the impact of the strength of European IP institutions on Chinese OFDI, given the different IP strength characteristics of the European countries in the sample, and distance from the Chinese IP institutions.

In doing so, we estimate various regression specifications, the explicit form of which is expressed as follows:

$$
\begin{aligned}
& O F D I_{i t}=a_{0}+a_{1} O{ } D I_{i t-1}+a_{2} G P_{i t}+a_{3} P O P_{i t}+a_{4} D I S T_{i t}+a_{5} I N F_{i t} \\
& +a_{6} R_{E E R_{i t}}+a_{7} O P_{i t}+a_{8} I P S_{i t}+a_{9} I P S_{i t}^{2}+a_{10} D U M_{i t} \\
& +a_{11} I P S * D U M_{i t}+u_{i t} \\
& u_{i t}=v_{i}+e_{i t}
\end{aligned}
$$

where $O F D I$ is outward foreign direct investment from China to European countries, GDP is the growth rate of the gross domestic product of the respective countries, $P O P$ denotes population, DIST is geographical distance between Beijing and the host capital cities in Europe, $I N F$ stands for the inflation rate, $E R$ is the exchange rate, $O P$ proxies a measure of trade openness and IPS is the Papageorgiadis et al. (2014) index of patent systems strength, IPS ${ }^{2}$ is the squared term, $D U M$ is the part member of FEB country dummy, and IPS*DUM is the interaction term; $u_{t}$ is the disturbance term, $v_{i}$ captures the unobserved country specific effect, while $e_{i t}$ is the idiosyncratic error. This is a one-way error component regression model, where $v_{i} \sim \operatorname{IIN}\left(0, \sigma^{2}\right)$ and independent of $e_{i t} \sim \operatorname{IIN}\left(0, \sigma^{2}\right)$. The descriptive statistics of the variables are provided in Table 5 below.

Apart from the GMM equations, alternative model specifications such as pooled and fixed effects models were also formulated and effectively estimated, but, due to the inherent inconsistencies permeating the dynamic specification of these models, we resorted to reporting only the most reliable estimates, i.e. the GMM-SYS estimates. A battery of robustness tests based on the econometric literature have been performed to ensure that the system-GMM estimator is free from instrument proliferation, weak instruments, and under-identification. In particular, Roodman (2009) shows that a great number of instruments can potentially result in an over-fitting of the model, hence producing biased estimations. In this case, Hansen tests may produce very high p-values. In view of the above, we adopted two ways of restricting the number of instruments used in the systemGMM estimations. The first is to collapse the instrument sets, and the second is to use specific lags instead of any possible lag length for instruments. The problems however of under-identification or weak instruments in the system-GMM estimations may persist even when the number of instruments has been reduced significantly (Bazzi \& Clemens, 2013; Murray, 2006). The strength of our instruments is therefore checked through the Kleibergen-Paap rk Wald F ( $\mathrm{K}-\mathrm{P}$ rk Wald F) statistic test. It should also be mentioned that a cross-correlation matrix (see Table 6 
Table 5. Descriptive statistics

\begin{tabular}{lccrr}
\hline \hline Variable & Mean & S.D. & Min & Max \\
\hline LOFDI & 2.3 & 3.0 & 1.1 & 4.2 \\
INF & 3.1 & 4.3 & -4.5 & 48.7 \\
GDP & 0.5 & 1.1 & -0.7 & 7.9 \\
LPOP & 7.5 & 7.5 & 6.6 & 8.2 \\
LOP & 2.0 & 1.6 & 1.7 & 2.3 \\
LDIST & 3.9 & 2.9 & 3.8 & 4.0 \\
LREER & 2.0 & 0.9 & 1.8 & 2.1 \\
IPS & 6.8 & 1.9 & 2.9 & 9.7 \\
\hline \hline
\end{tabular}

Table 6. Correlation coefficient matrix

\begin{tabular}{lcccccccc}
\hline \hline Variables & LOFDI & INF & GDP & LPOP & LOP & LDIST & LREER & IPS \\
\hline LOFDI & 1 & & & & & & \\
INF & 0.005 & 1 & & & & & \\
GDP & 0.53 & 0.04 & 1 & & & & & \\
LPOP & 0.38 & 0.386 & 0.85 & 1 & & & & \\
LOP & -0.21 & -0.12 & -0.5 & -0.53 & 1 & & & \\
LDIST & -0.02 & -0.3 & 0.003 & -0.26 & 0.04 & 1 & & \\
LREER & 0.21 & -0.32 & 0.14 & -0.07 & -0.07 & 0.2 & 1 & \\
IPS & 0.05 & -0.45 & -0.08 & -0.37 & 0.05 & 0.12 & 0.41 & 1 \\
\hline \hline
\end{tabular}

below) and a Variance Inflation Factor (VIF) were employed to check for multicollinearity. Both approaches suggested that existing collinear relationships were kept to a minimum, as the average VIF score was 3.6, when a common rule of thumb is that VIF scoring higher than 10 may constitute a legitimate cause for concern.

\section{RESULTS}

The results of the three models that test the effect of the strength of European IP institutions on Chinese OFDI are available in Table 7 below. ${ }^{[3]}$ With regards to Hypothesis la of our study, the evidence obtained from the first model shows a positive (at the 5\% level) relationship between Chinese OFDI and levels of IP institutional strength in European countries. Hypothesis la is therefore confirmed, in that strong IP institutions where the normative and cognitive structures are aligned with the regulatory structure and lead to the effective enforcement of IP, attract higher levels of Chinese OFDI. The magnitude of the effect suggests that a one unit increase in the index of Papageorgiadis et al. (2014) would be expected to cause Chinese OFDI flows to increase by $3 \%$. The result is consistent with the theoretical expectation and the results of the majority of existing studies on the relationship between IP institutions and OFDI from developed economies (e.g., Bascavusoglu \& Zuniga, 2002; Branstetter et al., 2007; Lee \& Mansfield, 1996; McCalman, 2004; 
Table 7. Effects of the strength of European IP institutions on Chinese OFDI

\begin{tabular}{|c|c|c|c|}
\hline & Model 1 & Model 2 & Model 3 \\
\hline LOFDI(-1) & $\begin{array}{c}0.736 \text { *** } \\
(15.99)\end{array}$ & $\begin{array}{l}0.748 * * * \\
(16.62)\end{array}$ & $\begin{array}{l}0.739 * * * \\
(16.03)\end{array}$ \\
\hline INF & $\begin{array}{c}0.004 \\
(1.202)\end{array}$ & $\begin{array}{c}0.004 \\
(1.149)\end{array}$ & $\begin{array}{c}0.004 \\
(1.042)\end{array}$ \\
\hline GDP & $\begin{array}{l}0.099 * * * \\
(4.068)\end{array}$ & $\begin{array}{l}0.114^{* * * *} \\
(3.89)\end{array}$ & $\begin{array}{l}0.12^{* * *} \\
(4.344)\end{array}$ \\
\hline LPOP & $\begin{array}{l}0.334^{* * * *} \\
(3.883)\end{array}$ & $\begin{array}{l}0.307 * * * \\
(3.675)\end{array}$ & $\begin{array}{l}0.293^{* * *} \\
(3.485)\end{array}$ \\
\hline LOP & $\begin{array}{l}0.407 * * * \\
(2.818)\end{array}$ & $\begin{array}{l}0.406^{* * * *} \\
(2.802)\end{array}$ & $\begin{array}{l}0.414 * * * \\
(2.856)\end{array}$ \\
\hline LDIST & $\begin{array}{l}-0.810^{* *} \\
(-2.097)\end{array}$ & $\begin{array}{c}-0.068 \\
(-0.132)\end{array}$ & $\begin{array}{c}-0.476 \\
(-1.172)\end{array}$ \\
\hline LREER & $\begin{array}{l}1.006^{*} \\
(1.822)\end{array}$ & $\begin{array}{c}0.907^{*} \\
(1.660)\end{array}$ & $\begin{array}{c}0.999^{*} \\
(1.812)\end{array}$ \\
\hline IPS & $\begin{array}{l}0.029 * * \\
(2.106)\end{array}$ & $\begin{array}{l}-0.176^{*} \\
(-1.628)\end{array}$ & $\begin{array}{l}0.035^{* *} \\
(2.397)\end{array}$ \\
\hline IPSSQR & & $\begin{array}{c}0.015^{*} \\
(1.854)\end{array}$ & \\
\hline DUM & $\begin{array}{c}0.004 \\
(0.93)\end{array}$ & $\begin{array}{c}0.035 \\
(0.583)\end{array}$ & $\begin{array}{c}0.47 * * \\
(2.024)\end{array}$ \\
\hline DUM*IPS & & & $\begin{array}{l}-0.085^{* *} \\
(-2.090)\end{array}$ \\
\hline Constant & $\begin{array}{c}-2.521 \\
(-1.383)\end{array}$ & $\begin{array}{c}-4.474^{*} \\
(-1.959)\end{array}$ & $\begin{array}{l}-3.688^{*} \\
(-1.882)\end{array}$ \\
\hline $\mathrm{AR}(1)^{\mathrm{a}}$ & 0.027 & 0.021 & 0.061 \\
\hline $\mathrm{AR}(2)^{\mathrm{b}}$ & 0.873 & 0.128 & 0.092 \\
\hline Hansen test ${ }^{\mathrm{c}}$ & 0.992 & 0.892 & 0.671 \\
\hline $\mathrm{K}-\mathrm{P}$ rank Wald test ${ }^{\mathrm{d}}$ & 0.00 & 0.00 & 0.00 \\
\hline Number of instruments & 34 & 28 & 32 \\
\hline
\end{tabular}

Notes: ${ }^{\mathrm{a}}$ Test for first-order serial correlation (p-values); ${ }^{\mathrm{b}}$ test for second-order serial correlation ( $\mathrm{p}$-values); ${ }^{\mathrm{c}}$ tests for validity of instruments; ${ }^{\mathrm{d}}$ Kleibergen-Paap rk Wald F - the results indicate that there is no under-identification problem for the difference model; Robust heteroskedastic-consistent standard errors are computed and robust $\mathrm{z}$ statistics are reported in parentheses; time dummies have been used in the estimation; *, ** and *** denote significance at $10 \%, 5 \%$ and $1 \%$ levels, respectively.

Ushijima, 2013). This is an important finding for the literature on OFDI from emerging countries (e.g., Hoskisson, Wright, Filatotchev, \& Peng, 2013; Luo \& Tung, 2007; Yamakawa et al., 2008), since this is the first study that identifies the importance of strong host country IP institutions for Chinese firms. In addition, given that most of the existing work in the area focused in the years prior to the implementation of the TRIPs agreement in the year 2000, the findings of this study demonstrate the continued importance of IP institutions after TRIPs. Importantly, while in the years prior to the implementation of the TRIPs agreement the strength of IP institutions appeared to matter for the OFDI decisions of firms from developed markets, the results showcase that in the years after TRIPs, the strength of IP institutions is also a determinant of the OFDI of firms from emerging markets. 
Chinese firms investing abroad in the 2003-2015 time period aimed to improve their competitiveness at the global level (Deng, 2013; Hong \& Sun, 2006; Wei et al., 2014) by fully exploiting their internally developed or acquired IP assets. Strong IP institutions in host European countries can enable Chinese firms to escape from the weak IP institutional framework existing in China (Luo et al., 2010; Yamakawa et al., 2008) and fully utilize their existing IP supported business models. This is because even if many of the Chinese firms are market leaders in China, the lack of a developed IP framework at home (Nolan, 2001; Rui \& Yip, 2008) can make it more difficult for Chinese firms to fully utilize their IP assets and efficiently appropriate the returns to their innovations (Teece, 1986). Therefore, operating in strong IP institutions can enable Chinese firms to utilize their IP portfolios and fully exploit the returns to their internally developed or acquired innovations (Lu, Liu, \& Wang, 2011; Ramasamy et al., 2012; Wei et al., 2014; Yiu et al., 2007). Operating in tight appropriability regimes, risks can be anticipated, and IP infringement can be successfully managed due to the effectiveness of the enforcement related institutional agents. Strong IP institutions can also allow Chinese firms to further develop and better utilize their business models, by, for example, achieving to effectively block competitors who may be infringing their IP (Cendrowski, 2017). It is important to note, however, that the magnitude of the identified effect of IP institutions on Chinese OFDI suggests that there is still a large percentage of unexplained variance that probably relates to the effect of other variables and perhaps the way that IP institutions interact with them, which will need to be examined further in future studies.

With regards to Hypothesis $1 \mathrm{~b}$, the weakly significant results of the second model suggest that the strength of European IP institutions might have a U-shaped relationship (at the 10\% level) with Chinese OFDI. While the significance level of the result is weak, it reveals a potentially different and intriguing pattern in that Chinese OFDI could be attracted by both strong and weak IP systems, but not moderate ones. Hypothesis $1 \mathrm{~b}$ is therefore not confirmed, however we find some evidence that European countries offering a moderate level of IP institutional strength may send negative mixed signals to Chinese investments (Papageorgiadis \& Sharma, 2016). European IP institutions of moderate strength may be unpredictable for Chinese firms which would prefer to avoid the risk of entering potentially lengthy and costly IP enforcement efforts when defending their IP assets or when being sued for the infringement of the IP of third parties.

The results of Model 3, which test Hypothesis 2, reveal that the effect of the strength of IP institutions on Chinese OFDI is moderated by a host country's past membership of the FEB. We find that the effect of the strength of IP institutions on Chinese OFDI is negative (at the 5\% level) when Chinese investments are directed to FEB countries. This result provides more support to the potential U-shaped effect of Hypothesis $1 \mathrm{~b}$ and particularly regarding the existence of the negative effect. The magnitude of the effect suggests that in countries that were members of the FEB, a one unit increase of the index of Papageorgiadis et al. (2014) 
would be expected to cause Chinese OFDI flows to decrease by $5 \%$. Therefore, the lower the strength of the IP institutions of FEB countries, the higher the Chinese OFDI received. When operating in FEB countries, Chinese firms can benefit from the incongruence of the normative and cognitive structures with the regulatory ones (Li et al., 2017) and the associated dominance of informal networking practices to mobilize the IP institutions (Buckley et al., 2007; Yiu et al., 2007). Chinese companies have established strong capabilities in developing business and institutional network ties with institutional agents in their home country where the institutional environment is similar to those of their targeted FEB countries (Meyer \& Peng, 2005; Peng, 1997; Peng \& Heath, 1996). Chinese businesses therefore perceive that the weaker the IP institution of a FEB country is, the higher the malleability of its institutional agents who could be influenced to support the firms' objectives (Brander et al., 2017; Peng et al., 2017). Chinese firms with business models that are either supported by established IP portfolios or not, anticipate influencing the IP institutions and mould them to achieve their desired (loose) appropriability conditions. Overall, this result provides more support and further explains the negative slope of the potential U-shaped effect in Model 2. The majority of the control variables included in the estimations have a significant effect on Chinese OFDI, bearing the expected sign in all three empirical models. First, the lagged OFDI variable is found to have a significant positive effect on Chinese OFDI indicating that past investments from Chinese firms in a host country tend to encourage future investment (Lipsey, 1999). Population is found to have a significant positive effect on Chinese OFDI (Chakrabarti, 2001). We also found GDP growth to have a significant positive effect on Chinese OFDI flows in Europe, result which is aligned with the theoretical expectations. In addition, market openness is also found to have a significant positive effect on Chinese OFDI. The exchange rate of a host country is found to have a weak positive effect in all three empirical estimations, suggesting that a depreciated exchange rate in a host country encourages inward FDI (Kohlhagen, 1977; Logue \& Willet, 1977; Stevens, 1993). Like Ramasamy et al. (2012) we find that inflation does not have an effect on Chinese OFDI. This result, however, is different from other studies (such as Buckley et al., 2007; Kang \& Jiang, 2012) that suggested a significant positive effect of inflation on Chinese OFDI. The insignificant role of inflation on Chinese OFDI in our study could be attributed to the time-period studied. Inflation rates have been less volatile in most European countries during the years 2003-2015 and therefore it could be expected that they neither posed a high risk, nor encouraged Chinese OFDI in the host economies. Finally, we find that geographic distance has a negative effect (at the $5 \%$ level) on Chinese OFDI in Model 1, but the result is not consistent across all estimations. While the result from Model 1 is aligned with the findings of the previous literature (Loungani et al., 2002), more research is needed to shed more light on the effect of geographic distance on Chinese OFDI, especially for investments directed at one specific geographic region (Europe). 


\section{DISCUSSION}

This article focuses on the variable levels of strength of the IP institutions of 23 European countries and studies their effect on Chinese OFDI over the period 2003-2015. We find that the strength of IP institutions has a positive effect in attracting higher levels of OFDI from China. This result provides the first empirical evidence in the literature on the importance of the strength of IP institutions for OFDI from EMs. This finding is aligned with the results of studies focusing on OFDI from developed countries, in that strong IP institutions provide desirable conditions that attract higher levels of OFDI (Nicholson, 2007; Seyoum, 2006; Smarzynska Javorcik, 2004). Strong IP institutions can enable Chinese IPowning firms, which are often market leaders in the Chinese market, to confidently engage in innovation activities in the host country as well as to effectively exploit their internally developed or acquired IP assets. This is because in countries with strong IP institutions, the normative and cognitive IP institutional structures are congruent and supportive to the (externally influenced due to TRIPs) IP regulatory structure. In such countries, IP institutional agents consider the regulatory structures as legitimate and acceptable, and effectively enforce IP law in practice.

We also find a weak indication of a potential U-shaped relationship between the strength of IP institutions and Chinese OFDI, result which is further supported by the finding that a country's membership of the FEB negatively moderates the effect of the strength of IP institutions on Chinese OFDI. When investing in FEB countries, Chinese firms may be attracted to weaker IP institutions due to the normative and cognitive general institutional similarities of the host countries with the institutional conditions in China. A common institutional characteristic in countries transitioning from centrally planned to market economies is the need for firms to develop business and institutional ties that can enable them to navigate and influence the institutional environment (Buckley et al., 2007; Yiu et al., 2007). Therefore, the weaker the IP institutional strength in a FEB host country is, the higher the opportunity for a Chinese firm to develop ties with institutional agents and, for example, avoid or minimize the impact of potential IP enforcement actions by competitors. Overall, Chinese investments appear to avoid investing in countries offering moderate levels of IP strength, probably due to the unpredictability of the institutional costs that Chinese firms may face when operating in such markets.

The results of this study raise important business and policy implications. For European and policy-makers from advanced economies, our study provides the first empirical evidence that the strength of national IP institutions attracts higher levels of OFDI from China. While the importance of the strength of IP institutions in attracting Chinese OFDI may have been underestimated in the past mainly due to the lack of available evidence, European policy makers need to, on the one hand, continue supporting the strengthening of their IP institutions and on the other, focus on understanding the specific challenges that Chinese 
firms face when dealing with European IP institutions. The latter is important because Chinese investments appear to avoid the IP institutions offering moderate levels of strength. European policy makers need to gain an understanding and provide support to Chinese firms that are potentially considering investing in countries offering moderate levels of IP institutional strength and at the same time countries with moderate IP institutional strength need to continue with the strengthening of their IP institutions in order to avoid this shortcoming in the future.

With regards to the implications for Chinese policy makers and businesses, the results indicate that the Chinese firms benefit from the strengthening of the IP institutions of foreign countries. In addition, Chinese firms which are in the process of exploring the potential to internationalize in European countries should consider to avoid investing in countries with moderate levels of IP institutional strength, since the IP institutional costs (actual and transaction costs) in these countries can be unpredictable. This is because Chinese firms with established IP portfolios may find it difficult to enforce their rights in such host countries, whereas firms with IP light business models may be faced with potentially disruptive IP enforcement actions against them. Chinese policy makers should consider raising the importance of strengthening IP institutions in their multilateral and bilateral negotiations with European countries. Importantly, the results of this study also highlight the importance for Chinese policy-makers to continue reforming Chinese IP institutions and to achieve higher levels of IP institutional strength more rapidly. This will benefit Chinese firms which develop their IP portfolios and integrate them in their business model and allow them to more effectively exploit their IP assets at home. It can also further motivate 'copycat' Chinese firms to transform into innovators (Peng et al., 2017), and exploit their innovations in foreign strong IP institutions. Finally, Chinese policy makers could consider developing a network of overseas IP- attachés (similar to the US and UK initiatives) in countries with moderate and weak IP institutions, to help internationalizing Chinese companies to navigate in the foreign IP institution and reduce their IP risks (IP Office, 2016; US Department of Commerce, 2016).

Overall, given that this is the first study looking into the effects of IP institutional strength on OFDI from an emerging country, future studies could provide further insights in the literature by considering some of the limitations of our study. Due to the lack of more disaggregated publicly available data, this study utilized aggregate country level OFDI data published by MOFCOM. Should more disaggregated data become publicly available in the future, studies could research the effects of IP institutional strength at the industry and firm level and include more countries in the empirical investigation. Having access to firm level data could also enable future studies to investigate whether the effect of host country IP institutional strength on OFDI from EMs is moderated by firm characteristics. Furthermore, future studies could investigate whether the effects of IP institutional strength are similar for the OFDI from other EMs, such as India and Brazil. This is

(C) 2019 The International Association for Chinese Management Research 
because OFDI by these emerging countries might be affected by IP institutional strength in different ways. For example, we can observe a similar pattern in OFDI from India, but also potential differences, particularly due to the IP related idiosyncratic behavior of the Indian pharmaceutical sector. A comparative approach is therefore suggested for future studies to identify the extent to which the results from this study can be generalized to OFDI from other EMs or developing countries.

\section{NOTES}

[1] The latest scores of the index of patent protection for the year 2010 are made available in Professor Park's (2017) personal website.

[2] It should be noted that we have run additional estimations for the same and different time periods, using alternative proxies for the size of the market such as income per capita (PPP), and the results are consistent with the reported estimations.

[3] It is important to mention that one of the concerns in the use of Chinese OFDI data is that Chinese investments abroad may be driven by policy (political) instead of business reasons. For example, the 'Opinions on Deepening the Reform of the Science and Technology System and Speeding up the Building of the National Innovation System' by the State Council of China in 2012 was a major initiative aimed at boosting the technological upgrading of Chinese firms. Such initiatives could dilute the results of studies since more Chinese firms may have embarked on OFDI from e.g. 2012 onwards, just to satisfy this national initiative, while the consideration of IP institutions may have been of secondary importance. We would like to highlight that during the review process, we have run the estimations using Chinese OFDI data for the years 1998-2011 and the results were fully consistent with the results reported here in terms of both direction of the effect and significance. Due to space considerations, the additional results are available upon request. We would like to thank the two anonymous reviewers and the Editor for this comment.

\section{REFERENGES}

Anderson, T. W., \& Hsiao, C. 1981. Estimation of dynamic models with error components. Journal of the American Statistical Association, 76(375): 598-606.

Anttonen, N., Tuunanen, M., \& Alon, I. 2005. The international business environments of franchising in Russia. Academy of Marketing Science Review, 2005(5): 1-18.

Arellano, M., \& Bond, S. 1991. Some tests of specification for panel data: Monte Carlo evidence and an application to employment equations. The Review of Economic Studies, 58(2): 277-297.

Arellano, M., \& Bover, O. 1995. Another look at the instrumental variable estimation of errorcomponents models. Journal of Econometrics, 68(1): 29-51.

Arosio, P., \& Masoni, D. 2015. ChemChina to buy into Italian tire maker Pirelli in $\$ 7.7$ billion deal. Reuters. [Cited 28 September 2017]. Retrieved from http://finance.yahoo.com/news/chem china-buy-italian-tire-maker-043531002.html\#

Bascavusoglu, E., \& Zuniga, M. P. 2002. Foreign patent rights, technology and disembodied knowledge transfer cross borders: An empirical application [Unpublished manuscript] France: University of Paris I.

Bazzi, S., \& Clemens, M. A. 2013. Blunt instruments: Avoiding common pitfalls in identifying the causes of economic growth. American Economic Joumal: Macroeconomics, 5(2): $152-186$.

Blonigen, B. A. 2005. A review of the empirical literature on FDI determinants. Atlantic Economic Journal, 33(4): 383-403.

Boisot, M., \& Meyer, M. W. 2008. Which way through the open door? Reflections on the internationalization of Chinese firms. Management and Organization Review, 4(3): 349-365. 
Bradshaw, T. 2017. Imagination technologies agrees $£ 550 \mathrm{~m}$ sale to Canyon Bridge. Financial Times. [Cited 29 September 2017]. Retrieved from https://www.ft.com/content/55d068608cac-36e9-92a2-3451760c3c42?mhq5j=e6

Brander, J. A., Cui, V., \& Vertinsky, I. 2017. China and intellectual property rights: A challenge to the rule of law. Journal of International Business Studies, 48(7): 908-921.

Branstetter, L., Fisman, R., Foley, C. F., \& Saggi, K. 2007. Intellectual property rights, imitation, and foreign direct investment: Theory and evidence NBER Working Paper, No. 13033, 1-44.

Buckley, P. J., Clegg, L. J., Cross, A. R., Liu, X., Voss, H., \& Zheng, P. 2007. The determinants of Chinese outward foreign direct investment. Journal of International Business Studies, 38(4): 499-518.

Canals, C., \& Şener, F. 2014. Offshoring and intellectual property rights reform. Journal of Development Economics, 108: 17-31.

Carruthers, B. G., \& Ariovich, L. 2004. The sociology of property rights. Annual Revieze of Sociology, 30: 23-46.

Caselli, F., Esquivel, G., \& Lefort, F. 1996. Reopening the convergence debate: A new look at crosscountry growth empirics. Journal of Economic Grozeth, 1(3): 363-389.

Cendrowski, S. 2017. Wait, Chinese bike-sharing doesn't make any sense. Forbes. [Cited 28 September 2017]. Retrieved from http://fortune.com/2017/03/21/chinese-bike-sharing/

Chakrabarti, A. 2001. The determinants of foreign direct investments: Sensitivity analyses of crosscountry regressions. Kyklos, 54(1): 89-114.

Changan UK. 2017. About us. changanuk.com. [Cited 28 September 2017]. Retrieved from http://www.changanuk.com/About-Us

Clark, A. 2010. Chinese carmaker Geely completes Volvo buyout from Ford. The Guardian. [Cited 28 September 2017]. Retrieved from https://www.theguardian.com/business/2010/aug/02/ volvo-ford-chinese-carmaker-geely

Cuervo-Cazurra, A., \& Genc, M. E. 2008. Transforming disadvantages into advantages: Developingcountry MNEs in the least developed countries. Journal of International Business Studies, 39(6): 957-979.

Cuervo-Cazurra, A., \& Genc, M. E. 2011. Obligating, pressuring, and supporting dimensions of the environment and the non-market advantages of developing-country multinational companies. Joumal of Management Studies, 48(2): 441-455.

De Leon, I., \& Donoso, J. F. 2017. Innovation, startups and intellectual property management: Strategies and evidence from Latin America and other regions. New York: Springer International Publishing.

Delios, A., \& Henisz, W. J. 2003. Political hazards, experience, and sequential entry strategies: The international expansion of Japanese firms, 1980-1998. Strategic Management Journal, 24(11): 1153-1164.

Deng, P. 2013. Chinese outward direct investment research: Theoretical integration and recommendations. Management and Organization Revieze, 9(3): 513-539.

Dunning, J. H. 2006. Towards a new paradigm of development: Implications for the determinants of international business activity. Transnational Corporations, 15(1): 173-229.

Filatotchev, I., Wright, M., Uhlenbruck, K., Tihanyi, L., \& Hoskisson, R. E. 2003. Governance, organizational capabilities, and restructuring in transition economies. Journal of World Business, 38(4): 331-347.

Geobytes.com. 2017. Distance calculator - find the distance between cities. Geobytes.com. [Cited 10 July 2017]. Retrieved from http://geobytes.com/citydistancetool/

Grossman, G. M., \& Lai, E. L. C. 2004. International protection of intellectual property. The American Economic Revieze, 94(5): 1635-1653.

Guler, I., \& Guillén, M. 2010. Institutions and the internationalization of US venture capital firms. Journal of International Business Studies, 41(2): 185-205.

Henisz, W., \& Swaminathan, A. 2008. Institutions and international business. Journal of International Business Studies, 39(4): 537-539.

Hitt, M. A., Ahlstrom, D., Dacin, M. T., Levitas, E., \& Svobodina, L. 2004. The institutional effects on strategic alliance partner selection in transition economies: China vs. Russia. Organization Science, 15(2): 173-185.

Holtz-Eakin, D. 1988. Estimating vector autoregressions with panel data. Econometrica, 56(6): 1371-1395.

Hong, E., \& Sun, L. 2006. Dynamics of internationalization and outward investment: Chinese corporations' strategies. The China Quarterly, 187(187): 610-634. 
Hoskisson, R. E., Wright, M., Filatotchev, I., \& Peng, M. W. 2013. Emerging multinationals from mid-range economies: The influence of institutions and factor markets. Journal of Management Studies, 50(7): 1295-1321.

Huawei Europe. 2015. About Huawei in Europe. huareei.eu. [Cited 28 September 2017]. Retrieved from https://huawei.eu/about-huawei

IP Office. 2016. UK attachés export intellectual property expertise across the globe. Intellectual Property Office and Baroness Neville-Rolfe DBE CMG. [Cited 28 September 2017]. Retrieved from https://www.gov.uk/government/news/uk-attaches-export-intellectual-property-expertise-across-the-globe

Justin, W. W., Tihanyi, L., Ireland, R., \& Sirmon, D. 2009. You say illegal, I say legitimate: Entrepreneurship in the informal economy. Academy of Management Revieze, 34(3), 492-510.

Kang, Y., \& Jiang, F. 2012. FDI location choice of Chinese multinationals in East and Southeast Asia: Traditional economic factors and institutional perspective.Journal of World Business, 47(1): 45-53.

Kanwar, S., \& Evenson, R. 2009. On the strength of intellectual property protection that nations provide. Journal of Development Economics, 90(1): 50-56.

Khoury, T. A., \& Peng, M. W. 2011. Does institutional reform of intellectual property rights lead to more inbound FDI?: Evidence from Latin America and the Caribbean. Journal of World Business, 46(3): 337-345.

Kohlhagen, W. 1977. The effects of exchange-rate adjustments on international investment: Comment. In P. B. Clark, D. E. Logue, \& R. Sweeney (Eds.), The effects of exchange rate adjustments: 194-197. Washington, DC: US Government Printing Office.

Kolstad, I., \& Wiig, A. 2012. What determines Chinese outward FDI? Journal of World Business, 47(1): 26-34.

Kondo, E. K. 1995. The effect of patent protection on foreign direct investment. Journal of World Trade, 29(6): 97-122.

Le Corre, P., \& Sepulchre, A. 2016. China's offensive in Europe. Washington, DC: Brookings Institution Press.

Ledeneva, A. 1999. Russia's economy offavours. Cambridge: Cambridge University Press.

Lee, J., \& Mansfield, E. 1996. Intellectual property protection and US foreign direct investment. The Revieze of Economics and Statistics, 78(2): 181-186.

Li, F., Butel, L., \& Wang, P. 2017. Innovation policy configuration - A comparative study of Russia and China. Policy Studies, 38(4): 311-338.

Li, Y. 2002a. Pushing for greater protection: The trend toward greater protection of intellectual property in the Chinese software industry and the implications for rule of law in China. Joumal of International Economic Law, 23(4): 637-661.

Li, Y. 2002b. The wolf has come: Are China's intellectual property industries prepared for the WTO? UCLA Pacific Basin Law Journal, 20(1): 77-112.

Lipsey, R. E. 1999. The location and characteristics of U.S. affiliates in Asia. NBER Working Paper, No. 6876: 1-34.

Logue, D. E., \& Willet, T. D. 1977. The effects of exchange - rate adjustments on international investment. In P. B. Clark, D. E. Logue, \& R. Sweeney (Eds.), Effects of exchange rate adjustments: 137-150. Washington, DC: US Government Printing Office.

Loungani, P., Mody, A., \& Razin, A. 2002. The global disconnect: The role of transactional distance and scale economies in gravity equations. Scottish Journal of Political Economy, 49(5): $526-543$.

Lu, J., Liu, X., \& Wang, H. 2011. Motives for outward FDI of Chinese private firms: Firm resources, industry dynamics, and government policies. Management and Organization Revieze, 7(2): 223-248.

Lu, J., Liu, X., Filatotchev, I., \& Wright, M. 2014. The impact of domestic diversification and top management teams on the international diversification of Chinese firms. International Business Revieze, 23(2): 455-467.

Luo, Y., \& Tung, R. L. 2007. International expansion of emerging market enterprises: A springboard perspective. Joumal of International Business Studies, 38(4): 481-498.

Luo, Y., Xue, Q., \& Han, B. 2010. How emerging market governments promote outward FDI: Experience from China. Journal of World Business, 45(1): 68-79.

Maskus, K. 2014. The new globalisation of intellectual property rights: What's new this time? Australian Economic History Revieze, 54(3): 262-284. 
McCalman, P. 2004. Foreign direct investment and intellectual property rights: Evidence from Hollywood's global distribution of movies and videos. Journal of International Economics, 62(1): 107-123.

Meyer, K. E. 2001. Institutions, transaction costs, and entry mode choice in Eastern Europe. Joumal of International Business Studies, 32(2): 357-367.

Meyer, K. E., \& Peng, M. W. 2005. Probing theoretically into central and Eastern Europe: Transactions, resources, and institutions. Journal of International Business Studies, 36(6): 600-621.

Meyer, K. E., Estrin, S., Bhaumik, S. K., \& Peng, M. W. 2009. Institutions, resources, and entry strategies in emerging economies. Strategic Management Joumal, 30(1): 61-80.

MOFCOM. 2009. Statistical bulletin of China's outward foreign direct investment. Beijing, China: China Statistics Press.

MOFGOM. 2015. Statistical bulletin of China's outward foreign direct investment Beijing, China: China Statistics Press.

Murray, M. P. 2006. Avoiding invalid instruments and coping with weak instruments. Journal of Economic Perspectives, 20(4): 111-132.

Nicholson, M. W. 2007. The impact of industry characteristics and IPR policy on foreign direct investment. Revieze of World Economics, 143(1): 27-54.

Nolan, P. 2001. China and the global economy. Basingstoke, UK: Palgrave Macmillan.

North, D. G. 1990. Institutions, institutional change and economic performance. Cambridge, UK: Cambridge University Press.

OECD. 2016. Inflation (CPI). [Cited 10 July 2017.]. Retrieved from https://data.oecd.org/price/ inflation-cpi.htm

Orr, R. J., \& Scott, W. R. 2008. Institutional exceptions on global projects: A process model.Journal of International Business Studies, 39(4): 562-588.

Ostergard, R. L. 2000. The measurement of intellectual property rights protection. Journal of International Business Studies, 31(2): 349-360.

Oxley, J. E. 1999. Institutional environment and the mechanisms of governance: The impact of intellectual property protection on the structure of inter-firm alliances. Joumal of Economic Behavior \& Organization, 38(3): 283-309.

Papageorgiadis, N., \& Sharma, A. 2016. Intellectual property rights and innovation: A panel analysis. Economics Letters, 141: 70-72.

Papageorgiadis, N., Cross, A. R., \& Alexiou, C. 2014. International patent systems strength 19982011. Journal of World Business, 49(4): 586-597. Data Retrieved from: http://www.liver pool.ac.uk/patent-systems

Park, W. G. 2008. International patent protection: 1960-2005. Research Policy, 37(4): 761-766. Data Retrieved from: http://fs2.american.edu/wgp/www/?_ga=2.195641513.4027611. 1526629987-939259333.1526629987

Peng, M. W. 1997. Firm growth in transitional economies: Three longitudinal cases from China, 1989-96. Organization Studies, 18(3): 385-413.

Peng, M. W., \& Heath, P. S. 1996. The growth of the firm in planned economies in transition: Institutions, organizations, and strategic choice. The Academy of Management Revieze, 21(2): 492-528.

Peng, M. W., Ahlstrom, D., Carraher, S. M., \& Shi, W. 2017. History and the debate over intellectual property. Management and Organization Revieze, 13(1): 15-38.

Pfister, E., \& Deffains, B. 2005. Patent protection, strategic FDI and location choices: Empirical evidence from French subsidiaries' location choices in emerging economies. International Journal of the Economics of Business, 12(3): 329-346.

Ramasamy, B., Yeung, M., \& Laforet, S. 2012. China's outward foreign direct investment: Location choice and firm ownership. Journal of World Business, 47(1): 17-25.

Roodman, D. 2009. How to do xtabond2: An introduction to difference and system GMM in Stata. Stata Journal, 9(1): 86-136.

Rugman, A. M., \& Li, J. 2007. Will China's multinationals succeed globally or regionally? European Management Journal, 25(5): 333-343.

Rui, H., \& Yip, G. S. 2008. Foreign acquisitions by Chinese firms: A strategic intent perspective. Journal of World Business, 43(2): 213-226.

Schliessler, P. M. 2015. Patent litigation and firm performance: The role of the enforcement system. Industrial and Corporate Change, 24(2): 307-343.

Scott, W. R. 1995. Institutions and organizations. London: Sage. 
Seyoum, B. 2006. Patent protection and foreign direct investment. Thunderbird International Business Reviez, 48(3): 389-404.

Smarzynska Javorcik, B. 2004. The composition of foreign direct investment and protection of intellectual property rights: Evidence from transition economies. European Economic Revieze, 48(1): 39-62.

Stevens, G. V. G. 1993. Exchange rates and foreign direct investment: A note. idea.respect.org [Cited 10 August 2017]. Retrieved from https://ideas.repec.org/p/fip/fedgif/444.html

Taubman, A., Wager, H., \& Watal, J. 2012. A handbook on the WTO TRIPS agreement. Cambridge, UK: Cambridge University Press.

Teece, D. J. 1986. Profiting from technological innovation: Implications for integration, collaboration, licensing and public policy. Research Policy, 15(6): 285-305.

The World Bank. 2017. Data. Indicators. [Cited 10 July 2017]. Retrieved from https://data.world bank.org/indicator

Thomas, K. 2017. Implementing the TRIPS agreement in China: The World Trade Organisation TRIPS agreement. In K. Thomas (Ed.), Assessing intellectual property compliance in contemporary China: 85-103. Singapore: Springer.

UNCTAD. 1998. World investment report 1998: Trends and determinants: $1-432$.

Unified Patent Court. 2017. A single patent court covering 25 countries. [Cited 28 September 2017]. Retrieved from https://www.unified-patent-court.org/

US Department of Commerce. 2016. USPTO attachés: A valuable resource for U.S. intellectual property interests abroad. [Cited 28 September 2017]. Retrieved from https://www.com merce.gov/news/blog/2016/11/uspto-attaches-valuable-resource-us-intellectual-property-inter ests-abroad

Ushijima, T. 2013. Patent rights protection and Japanese foreign direct investment. Research Policy, 42(3): 738-748.

Wageningen University. 2014. Chinese dairy giant Yili opens R\&D centre at Wageningen Campus. [Cited 28 September 2017]. Retrieved from https://www.wur.nl/en/newsarticle/Chinesedairy-giant-Yili-opens-RD-centre-at-Wageningen-Campus.htm

Walsh, J., \& You, J. 2010. Determinants of foreign direct investment: A sectoral and institutional approach. IMF Working Paper, 10(187): 1-27.

Wei, Y. Q., Zheng, N., Liu, X. H., \& Lu, J. Y. 2014. Expanding to outward foreign direct investment or not?: A multi-dimensional analysis of entry mode transformation of Chinese private exporting firms. International Business Revieze, 23(2): 356-370.

WHO. 2017. WTO and the TRIPS agreement. [Cited 28 September 2017]. Retrieved from http:// www.who.int/medicines/areas/policy/wto_trips/en/

WIPO. 2016. Global patent applications rose to 2.9 million in 2015 on strong growth from China; Demand also increased for other intellectual property rights. [Cited 28 September 2017]. Retrieved from http://www.wipo.int/pressroom/en/articles/2016/article_0017.html

WIPO. 2017. Statistical country profiles. [Cited 28 September 2017]. Retrieved from http://www. wipo.int/ipstats/en/statistics/country_profile/profile.jsp?code=CN

Witt, M. A., \& Lewin, A. Y. 2007. Outward foreign direct investment as escape response to home country institutional constraints. Joumal of International Business Studies, 38(4): 579 594.

Yamakawa, Y., Peng, M. W., \& Deeds, D. L. 2008. What drives new ventures to internationalize from emerging to developed economies? Entrepreneurship Theory and Practice, 32(1): 59-82.

Yang, D., Fryxell, G. E., \& Sie, A. K. Y. 2008. Anti-piracy effectiveness and managerial confidence: Insights from multinationals in China. Journal of World Business, 43(3): 321-339.

Yiu, D. W., Lau, C., \& Bruton, G. D. 2007. International venturing by emerging economy firms: The effects of firm capabilities, home country networks, and corporate entrepreneurship.Journal of International Business Studies, 38(4): 519-540.

Zhang, X., \& Yan, W. 2017. Mobike's secret to leading the bicycle pack-business. China Daily. [Cited 28 September 2017]. Retrieved from http://www.chinadaily.com.cn/business/201703/27/content_28687163.htm 
Nikolaos Papageorgiadis (n.papageorgiadis@liverpool.ac.uk) is a Senior Lecturer in International Business at the University of Liverpool Management School, UK. His research focuses on the effects that Intellectual Property (IP) systems have on the business strategy of firms. He is a regular keynote speaker and presenter at international IP specialist practitioner conferences, and his research informs policymakers and the international patent filing practices of firms. He has received excellence awards for his teaching and training practice in relation to learner engagement and technology enhanced learning.

Yue Xu (xuy63@cardiff.ac.uk) is an Assistant Professor in International Business and Management at the Cardiff Business School, UK. Her current research focuses on examining institutional theories for explaining strategic behaviours of emerging market multinationals, with results published on academic journals and presented to many international conferences. She is also actively engaged in the teaching of MBA students and training of doctoral researchers. Since 2012, she has been a visiting fellow and a research associate of the Wolfson College of the University of Cambridge.

Constantinos Alexiou (constantinos.alexiou@cranfield.ac.uk) is an Associate Professor in Applied Economics at Cranfield School of Management, UK, where he delivers business related courses across the full range of the School's postgraduate and post-experience executive management programmes. He holds visiting teaching and research professorial appointments at various Universities across the World. He has authored a great number of publications in academic journals and he is a frequent contributor to many international conferences.

Manuscript received: January 5, 2017

Final version accepted: July 5, 2018 (number of revisions - 3)

Accepted by: $\quad$ Senior Editor Bent Petersen 